\title{
Small Claim Court as The Alternative of Bad Credit Settlement for Legal Certainty of The Economic Actors
}

Pujiyono $^{1 凶(\mathbb{D})}$; Umi Khaerah Pati ${ }^{2}{ }^{(\mathbb{D})}$; Pranoto ${ }^{3}$; Kukuh Tejomurti ${ }^{4}$ 1,2,3,4 Faculty of Law Universitas Sebelas Maret

Corresponding author: pujifhuns@staff.uns.ac.id

Abstract: The purpose of this paper was to look into the issue of legal cases accumulating on credit contracts in court. It also assesses the efficacy of establishing a minor claim court in the event of contract default. Small claim court will also provide a milestone in settlement of bad debts resulting from contract defaults, reducing the burden on Indonesian courts and providing legal certainty to business actors. Inheritance cases are also examined, resolved, and decided by the sole judge in a timely and efficient manner, resulting in a reasonable assessment for all participants. This normative study used statutory, case, comparative law, and analysis content approaches. The research results showed that Small Claims Court is a court that conducts a trial and renders a binding judgment that can be enforced like any other judgment. Although Small Claims Court can be less formal and less strict when it comes to admitting evidence, the court's judgment is as strong as anything else provided by the judicial system. The filing of small claim court increased ten times from 2015 to 2020, with the plaintiffs dominated by banks in lousy credit cases. A small claim court provides benefits to the bank and the customer because it speeds up the settlement of the plaintiff's money in a bad credit case with a case value of not more than 500 million, and There are no provisions, exceptions, reconventions, interventions, replicas, duplicates, or conclusions in the case examination process.

Keywords: court; default; small claim court

\section{How to cite:}

Pujiyono, P., Pati, U., Pranoto, P., \& Tejomurti, K. (2021). Small Claim Court as the Alternative of Bad Credit Settlement for Legal Certainty of the Economic Actors. Indonesian Journal of Advocacy and Legal Services, 3(2). https://doi.org/10.15294/ijals.v3i1.48136 


\section{P. Pujiyono, U. M. Pati, P. Pranoto, \& K. Tejomurti}

\section{A. Introduction}

What is a small claims disputes all about? The answer is not a simple one. Almost a decade ago Hennessey (1975) observed that though a claim may be small in monetary terms, the disputes and the issues underlying the dispute may be very complex. Sometimes there is a hidden agenda. Sometimes the small claim dispute may be a skirmishing point whose real, unarticulated cause lies elsewhere. However, one need not pursue matters to this point to realize that the plaintiff's demand for compensation does not necessarily capture the difference between the parties. In monetary terms alone, it is clear that the plaintiff's claim does not define the dispute, for a defendant may be willing to concede that a portion of what is sought is owing. If so, an award to the plaintiff may actually confirm the defendant's version of the disputed transaction. ${ }^{1}$

Yahya Harahap (2010) stated that the average time needed to settle a case from the first instance to the cassation is 7 to 12 years. ${ }^{2}$ However, in practice, the judicial process takes a long time in resolving cases, such as when the losing party does not receive a decision and submits legal remedies in the form of an appeal or cassation. This causes the decision to have no permanent legal force (res judicata), leading to a buildup of cases(Harahap 2009). In the context of a business contract dispute, examinations that take a prolonged period negatively affect legal uncertainty, which tends to impact business certainty with economic value. ${ }^{3}$ Since business conflicts demand a quick and straightforward resolution, court expenses are lower whenever a settlement is reached that is acceptable to all parties without extending or causing new problems.

One of the most severe issues in the court system is case accumulation. This is due to the ineffectiveness of judicial implementation non-accordance with the three principles of justice: speed, simplicity, and low cost To respond to these principles, the Supreme Court established a policy by establishing a "small claim court" based on the application of small claim courts in numerous nations, including the United States. According to Supreme Court Regulation, the examination process takes 25 days to obtain a conclusion, and there are no other legal remedies available, such as appeals or cassation.

\footnotetext{
1 Vidmar, N. (1984). The small claims court: A reconceptualization of disputes and an empirical investigation. Law and Society Review, 515-550.

2 M. Yahya Harahap, (2010), Beberapa Tinjauan Mengenai Sistem Peradilan dan Penyelesaian Sengketa, Rajawali: Jakarta, p. 154

3 Tejomurti, K. (2017). Pertanggungjawaban Hukum yang Berkeadilan Terhadap Aparatur Pemerintah pada Kasus Pengadaang Barang dan Jasa. Dialogia Iuridica: Jurnal Hukum Bisnis Dan Investasi, 8(2), pp.42-52.
} 
The ideal approach for businesses, such as banks, to settle the problem of bad credit in the microcredit sector is through a small claim court. Due to Supreme Court decisions on small claim courts, the Indonesian Banking Association reported an increase in recovery received in bad credit cases from 2.1 percent in 2018 to 3.2 percent in 2019

However, several parties claimed that the settlement of matters in singlejudge trials is governed by Supreme Court Regulation, which mandates that the panel of judges is composed of at least three judges. This is, however, a far cry from the judgment reached by the judges' panel following debates, which included dissenting perspectives on the judge's discretion in deciding cases. Furthermore, the Supreme Court Regulation's position in assessing a single judge's ability to govern a minor claim court is not deemed to be in the legal hierarchy

Based on the description above, this study aims to determine the effectiveness of the small claim court implementation in the default case on credit contracts. Secondly, this study determines the independence of a single judge in the process of examining a small claim court in the default case on credit contracts.

\section{B. Methods}

This research blends legal research with qualitative research. The provisions of the small claim court are examined in this article, as well as their application in the resolution of bad credit situations. The authors give the facts of a growing number of judicial cases. The writers also discuss how the small claim court system may help banks and customers address problems, as well as its benefits over the traditional judicial proceedings from submission to trial to verdict and appeal.

\section{Result and Discussion}

\section{Small Clime Court as An alternative Sattelment of Bad Credit Case in Indonesia}

What is a small claims disputes all about? The answer is not a simple one. Almost a decade ago Hennessey (1975) observed that though a claim may be small in monetary terms, the disputes and the issues underlying the dispute may be very complex. Sometimes there is a hidden agenda. Sometimes the small claim dispute may be 


\section{P. Pujiyono, U. M. Pati, P. Pranoto, \& K. Tejomurti}

a skirmishing point whose real, unarticulated cause lies elsewhere. However, one need not pursue matters to this point to realize that the plaintiff's demand for compensation does not necessarily capture the difference between the parties. In monetary terms alone, it is clear that the plaintiff's claim does not define the dispute, for a defendant may be willing to concede that a portion of what is sought is owing. If so, an award to the plaintiff may actually confirm the defendant's version of the disputed transaction.

A first step in saving nonperforming loans prior to taking them to court is to take supervision deeds, which include advising on improving business conditions by assisting debt holders in finding new markets and clients. The next step is to save the credit portfolio of assets, including restructuring, reconditioning, and rescheduling. If you can't avoid it, take non-lawsuit measures first and consider litigation as a last resort. The court as a venue for dispute settlement has several benefits, and it is also an institution that is employed to seize and perform out executions. ${ }^{4}$ According to World Bank study, there are various barriers to settling commercial disputes through the courts in Indonesia, including 1.) inefficient first-level dispute resolution, 2.) protracted settlement timelines, 3.) high court costs, and 4.) exorbitant attorney fees. The processing of claims for fiat execution through the courts takes a lengthy time, whereas the measurement of credit losses (interest) continues and cannot be postponed. It can take up to two years on average; some people have even run for four years and still haven't finished. $\underline{5}$

The inefficiency and prolonged period lead to the accumulation of case files in court. Based on the 2016 Supreme Court report, a total of 83,943 civil cases were tried by district courts throughout Indonesia in 2016. Of this number, 71,456 cases were received in 2016, and the remaining 12,487 in 2015. Furthermore, 59,993 of these cases were decided in 2016, and 6,843 were withdrawn, leading to 17,107 cases by the end of December 2016. ${ }^{6}$ As a result, the Supreme Court Regulation was published, which was aimed to promptly and simply determine

4 Raynaldo B, (2018), Kebebasan Bank Dalam Memilih Lembaga Penyelesaian Kredit Macet Di Indonesia, Lex Privatum Vol. Vi/No. 1/Jan-Mar/2018, p. 145

5 Arifin, R. (2020). Legal Reform Discourse in Indonesia and Global Context: How Does The Law Respond to Crime. Journal of Law and Legal Reform, 1(2), 193-196.

6 Ariani, N. V. (2018). Gugatan Sederhana dalam Sistem Peradilan di Indonesia. Jurnal Penelitian Hukum pISSN, 1410, 5632 . 


\section{Small Claim Court as the Alternative of Bad Credit Settlement}

responses to legal challenges presented by parties regarding Small Claims Court Procedures. Cases resolved under this statute, on the other hand, are handled by a single judge and necessitate a quick and brief examination and settlement period with simple proof.

In a small claim court, lawsuits with a maximum value of $\$ 500$ million are allowed if both the defendant and the plaintiff are residents of the same territory. The number of plaintiffs and defendants cannot exceed one unless they share the same legal interest, are examined by the same judge, and are decided by the same judge. A preliminary examination is undertaken before to the trial. The judge in the case has the authority to rule that a matter is not simple and to strike it from the registration, as well as to force the plaintiff to pay the remaining court fees. When a single judge is available, the Chief Justice appoints a single judge to examine a small claim court, aided by the clerk, with the plaintiff and defendant in attendance. There are no provisions, exceptions, reconventions, interventions, replicas, duplicates, or conclusions in the case examination process because there are just claims and responses. The limitation period for lawsuit settlement is 25 days from the start of the first trial, as opposed to the standard court's maximum of 5 months. Objections must be filed within 7 days of the judges' decision, and there are no appeals or cessation options. The case is ruled void if the plaintiff fails to appear at the first hearing for no justifiable cause. Furthermore, if the defendant is not present on the first trial day, a second summons is issued, and if this occurs on the second trial day, the judge is capable of deciding the case. The litigation is investigated and determined on a contradictory foundation, in which the defendant is permitted to raise an objection if the defendant is present at the first trial but missing at future ones for no justifiable cause..

The judge is still advised to obtain peace at the first trial, and once this is accomplished, a Deed of Peace is issued that binds both parties. When the situation is reversed, however, no legal action is taken. When a judge examines the applicable procedural law, recognized claims do not need to be substantiated against those that were refused. In a public trial, the judge is required to read the decision and inform the parties of their rights. In a minor claim court, the legal remedy is to file an objection to the Chief Justice by completing the related deed in 


\section{P. Pujiyono, U. M. Pati, P. Pranoto, \& K. Tejomurti}

front of the clerk. Objections must be filed within 7 (seven) days of the verdict being announced.

\section{The Effectiveness of a Small claim court in Bad Credit Cases}

According to several studies in Supreme Court Regulation No. 4 of 2019 concerning Amendments to Supreme Court Regulation No. 2 of 2015, there are advantages and disadvantages associated with the Procedures for Settlement of Small claim court. The following describes some of the 2019 Supreme Court Regulation rules regarding small claim court against credit cases from the application, trial, decision, and implementation stages.

\section{a. Application stage}

Article 3 of the 2019 Supreme Court Regulation stated that non-performing loans are resolved through a small claim court as long as the object of the case is not more than IDR 500,000,000 (two hundred million rupiahs). As a result, a substantial litigation worth more than $\$ 500$ million is unresolvable. In actuality, commercial banks can provide larger loans as long as they follow the regulations set forth in the Financial Services Authority Regulation of the Republic of Indonesia Number 32 /Pojk.03/2018 on the Maximum Limit for Loans and Provision of Large Funds for Commercial Banks. The maximum credit limit for a single debtor or a group of creditors is $10 \%$ of the bank's core capital or greater (tier 1). As a result, if the bank belongs into the book 4 categories and has a minimum core capital of 30 trillion, the maximum loan issued to consumers is enormous. As a result of this law, a small claim court can only deal with a tiny portion of bank non-performing credit disputes, such as bad credit on People's Business Credit (KUR) loans worth between IDR 5 million and IDR 500 million, and consumer financing loans like credit cards. One of the factors that must be met at the preliminary examination stage is that the debt value does not exceed IDR 500 million when a case goes to court. This is the most crucial stage because the judges determine whether the lawsuit is included in the simple category or not by assessing the proof's simplicity. When the judges consider that the lawsuit is not in the simple category, they tend to delete it from the 
cash register and order the remaining court fees to be returned to the plaintiff.

The following administrative need has to do with residency. In a small claim court, the Plaintiff and Defendant must be domiciled in the same court region, according to Article 4 paragraph (3) of the Supreme Court Regulation. This indicates that the parties will be unable to use this small claim court if there are legal domicile discrepancies. The 2019 Supreme Court Regulation, on the other hand, established a new policy for plaintiffs with jurisdictions other than the defendant's to ensure that they can file a lawsuit by designating a proxy, incidental attorney, or institutional representation domiciled in the defendant's jurisdiction. The cases can be submitted remotely using electronic case administration (e-court). The previous requirement (2015) does not burden the banks because, in practice, they are very selective on applications submitted by prospective customers domiciled outside the reach of their business area. For example, a credit card is easily issued by a bank when a domicile certificate is attached according to the coverage area. An instance of this scenario is issuing a credit card by BRI Bank Waru Sidoarjo Branch, East Java. In carrying out this activity, the customers must be domiciled in Sidoarjo, and foreigners (Foreign Citizens) are not allowed to register. These rules are made for banks to easily analyze the condition of prospective customers, guarantee collaterals and anticipate the occurrence of future bad credit. Furthermore, the actor sequitur ferum rei principle can be implemented at the lower cost.

\section{b. Trial Stage}

The judge in a small claim court is appointed by the chairman of the court (Article 1 paragraph 1 Perma 2019). ${ }^{7}$ In Indonesia, at least 3 judges are expected to examine and decide court cases. This is regulated in the Law on Judicial Power Article 11 paragraph (1) and (2) of the Law on Judicial Power.

(1) The court examines, adjudicates, and decides cases with a panel of at least 3 (three) judges unless the law states otherwise.

$7 \quad$ Laras Asri Dwi Permatasari, (2019), Procedure and Implementation of Bank Bri Customers' Credit Cards Waru Sidoarjo Branch, , Thesis, Perbanas School of Economics Surabaya, p. 9 
(2) The composition of the judges referred to in paragraph (1) consists of a presiding judge and two member judges.

Apart from the 2019 Supreme Court Regulation regarding small claim court, several judicial regulations authorize judges to examine and decide cases, including juvenile courts. This is in accordance with Article 11 paragraph (1), Article 14 paragraph (1), Article 18 paragraph (1) of Law Number 3 of 1997 concerning Juvenile Court, as well as Article 44 paragraph (1), Article 47 paragraph (1), and Article 50 paragraph (1) Law Number 11 of 2012 concerning the Juvenile Criminal Justice System, where judges examine and decide on children's cases both at the first, appeal and cassation levels. Furthermore, the examination of tax dispute regulated in Article 65 to Article 68 of Law no. 14/2002 on the Tax Court is carried out by a panel or single judge. The advantage of a single judge in making decisions is that it speeds up the trial process by reducing deliberation by the panel of judges. On the other hand, a single judge's decision can be subjective and rushed due to the unavailability of a question and answer process.

A judge is a self-contained human who uses himself or her own ideology as a moral framework to investigate and decide a case. There are different styles of small claim court judges in the trial, according to Karen Tracy: (a) strict (b) legislative (c) authoritative (d) mediator, and (e) procedural. A judge has three legal purposes, according to Gustav Radbruch: certainty (Rechtssicherheit), justice (Gerechtigkeit), and expediency (Zweckmaszigkeit). These legal goals, on the other hand, are not always in sync; in fact, they are frequently at odds (Spannungsverhaltnisse). As a consequence, the priority principle must be employed in order to meet these three legal aims. As according Gustav Radbruch, there is a hierarchy scale that should be fulfilled, with justice coming first, then benefits, and finally legal certainty. As a result, a judge must effectively manage these three essential principles by avoiding extrajudicial interference or pressure, particularly from plaintiffs. The impartiality and political insularity of judges are both put to the test. The notion of judicial impartiality is reflected in legal arguments and decisions that have no vested interest in the case, but the principle of political actor decisions is reflected in the fairness of decisions and recognized by people seeking justice. $\underline{8}$

8 A. Muhammad Asrun, "Krisis Peradilan: Mahkamah Agung di bawah Suharto", (Jakarta: ELSAM, 2004), p. 45 


\section{Small Claim Court as the Alternative of Bad Credit Settlement}

In the end, all judge's decisions should be based on legal grounds. Parties are expected to accept the judgment and seek restitution if they consider others and vice versa have violated their rights. The Indonesian Supreme Court has decided that any judge's decision should include all legal, philosophical, and sociological issues; consequently, the justice that must be accomplished, realized, and accounted for is legal, moral, and social justice-oriented. According to Article 5 paragraph (1) of Law no. 48 of 2009 concerning Amendments to the Law on Judicial Power, judges are required to investigate the legal values that exist in a community. In examining instances, their judgment results from a fight between mind and conscience. Judex Facti (First Level Court and Appellate Level) expresses its opinion based on facts that appear legally at the trial. Therefore inductive thinking methods equipped with legal skill competency standards are needed to analyze the cases based on existing facts and appropriate law. Therefore, even though it only consists of a single judge, the decision needs to be always considered correct, as the legal principle of res judicata pro veritate habetur.

Article 4 paragraph (4) of the Supreme Court Regulation Number 2 of 2015 stated that the plaintiff and the defendant are obliged to attend the trial process with or without being accompanied by a legal representative. Small claim court do not have to be represented by a legal representative or by employing the services of an advocate, as is the case in ordinary civil lawsuits. However, the plaintiffs and defendants need to attend the trial with or without legal counsel. The lawsuit is declared void, supposing the commercial bank as the plaintiff is not present at the first trial without a valid reason. Furthermore, when the customer is not present at the first trial, a second summons is made, and when this fails, a verstek precides over the case. Cases decided by verstek are considered formal, thereby preventing the defendant from refilling the case except by submitting a fight, also known as a verzet. According to article $129 \mathrm{HIR}, \underline{9}$ the verzet grace period for ordinary claims can be submitted directly to the defendant within

9 Darmawati and Asriadi Zainuddin, (2015), Application of Verstek Decisions at the Religious Courts of, Al-Mizan Issn 1907-0985 E Issn 2442-8256 Volume 11 Nomor 1, pp. 90-101 Http://Journal.Iaingorontalo.Ac.Id/Index.Php/ Am p. 98 
14 days after the decision. (Darmawati and Zainuddin 2015). However, in a small claim court, the period given by the Supreme Court Regulation is shortened to only 7 days. Therefore, when the Defendant/Respondent submits a verzet, the examination is continued by summoning the parties back to the trial. In cases whereby the defendants are present at the first trial and absent on the next without valid reasons, they are tried in a contradictory manner (Darmawati and Zainuddin 2015).

On the first day of the trial, the judge must seek peace between the bank and the customer. Supposing this is reached, the judge makes a peace deed that binds both parties. However, there is no legal remedy when the associated parties are against the decision. This peace was once broken in the case of bad credit between PT. Rural Bank NBP 5 against Lisbon Manurung as Defendant I, and Tetty Herawati Jawak as Defendant II. The dispute ended with the decision of the peace deed because of the good faith of the parties involved (Saputri 2019). Furthermore, it contained contents of the peace agreement and the judge's decision that strengthens it, which is not subject to ordinary or extraordinary legal remedies. This is in accordance with the agreement of both parties in court mediation, whose position is similar to the judge's decision which has permanent legal force (inkracht van gewijsde). However, this is related to Article 130 of HIR (2), which stated that "When peace occurs, at the time of the trial, a deed needs to be made that requires both parties to fulfill the agreement made, thereby making it valid and carried out by an ordinary judge's decision." 10 Therefore, based on the article above, it is concluded that the peace deed is inkracht van gewijsde and has executive power. In this decision, the peace deed starts with the sentence "For Justice Based on the One Godhead" the judge is also going to include a dictum, such as "Punish both parties (plaintiff and defendant) to carry out the contents of the peace deed." This dictum is an order, which needs be carried out by the parties. Article 130 (2) HIR stated that the parties are basically obliged to obey and fulfill the contents of the peace agreement. Furthermore,

10 Lisma Resky Saputri, Kahar, Sulaeman, Legal Analysis of Bad Credit Cases at Bank Rakyat Indonesia Majene Branch Number: 35/Pdt.G.S/2018/Pn.Mjn, University of West Sulawesi 
paragraph (3), stated that such a decision are not permitted to use legal remedies. Therefore, the privileges of the peace decision are closed appeals and cassation proceedings, have permanent legal force, and executive power. 11

Once the litigants cannot come to an agreement, an examination of the main matter is characterized by reading the plaintiff's "lawsuit" followed by a response from the defendant. Provisions, exceptions, conventions, interventions, replicas, duplicates, and conclusions, unlike conventional lawsuits, cannot be filed in small claim court because it moves straight to the evidence procedure..

A claim that is recognized and denied by the defendant does not need to be proven. However, on the contrary, when there is a rebuttal from defendant, the examination of evidence is based on the Procedural Law. For example, in the Bad Credit Case of Bank Rakyat Indonesia Majene Branch Number: 35/Pdt.GS/2018/ PN.Mjn, the defendant admitted to having defaulted by not paying the debt installments that had to be repaid. Therefore, the judge granted the plaintiff's arguments and mandated the defendant to pay all credit areas in full. In situations where the defendant refuses to voluntarily pay all arrears, the collateral is auctioned with the intermediary of the State Assets Service and Auction Office (KPKNL), the judge orders for an immediate evacuation of the object. Furthermore, in situations whereby the defendant fails to conduct the job properly, the plaintiff, with the assistance of the authorities, carries it out and mandates the defendant to pay the costs incurred.

\section{c. Decision Stage}

Banks are frequently sued by debtors who do not want their assets/guaranteed to be auctioned during the auction of debtors' assets/guaranteed..$^{12}$ Essentially, once a court ruling has permanent legal force, the losing party must voluntarily carry out

11 Mareti Gulo, Monique Imaniar Putri, 2018, “Analisis Hukum Terhadap Penyelesaian Sengketa Hutang Piutang Melalui Akta Perdamaian (Studi Putusan Nomor: 1/Pdt.G.S/2017/Pn. Blg)”, Jurnal Hukum Kaidah Media Komunikasi Dan Informasi Hukum Dan Masyarakat, Volume :18, Nomor : 3 Issn Online : 2613-9340 Issn Offline: 1412-1255, pp. 108-109.

12 Ismiyanto, 2018, "Penyelesaian Kredit Bermasalah Melalui Gugatan Sederhana Berdasarkan Peraturan Mahkamah Agung (Perma) No. 2 Tahun 2015 tentang Tata Cara Penyelesaian Gugatan Sederhana”, Jurnal Spektrum Hukum, Vol. 15/No. 2. 


\section{P. Pujiyono, U. M. Pati, P. Pranoto, \& K. Tejomurti}

its terms. When the losing party fails to carry out the decision freely by submitting a request for execution to the Head of the District Court, for example, execution must be carried out by the winning party. The request for execution is the basis for issuing a warning or aanmaning. $\frac{13}{}$ Through a small claim court, Article 31 paragraph 2(a) of the Supreme Court Regulation of 2019 enables the judge to issue a security decision no later than 7 (seven) days after receiving the execution request letter. The decision is to be complied with in line with the provisions of the applicable civil procedural law. The Court Registrar examines the conservatoire confiscation first on the property of the execution defendant. This is because, based on Article 17 A of the 2019 Supreme Court Regulation, the judge is authorized to implement a security confiscation on the defendant's property, such as a credit guarantee object. In line with the provisions of Article 197 paragraph (1) of HIR, confiscation is first carried out on movable goods. However, when these goods are unavailable or insufficient, then immovable goods are utilized. Security confiscation is carried out by order of the judge before or during the examination process, and for the confiscation, the judge makes a letter of determination. Confiscate guarantee is carried out by the Registrar or Bailiff accompanied by 2 (two) District Court employees as witnesses. Before determining the application for a confiscation guarantee, the judge is obliged to pay attention to the following matters: 1) ensure that confiscation is only carried out on the defendant's property or goods. An instance is in the case of revindicatoir confiscation of certain movable goods belonging to the plaintiff in the hands of the defendant, after first hearing the statement in accordance with Article 227 Paragraph (2) HIR and Article 261 Paragraph (2) RBg) 2). Supposing the confiscation is a plot of land with or without a house, it needs to be registered in line with the provisions in Article 227 Paragraph (3) jo. Article $198 \mathrm{HIR}$ / article 261 jo. Article 213 and Article 214 RBg.

3) The confiscated land need to be already registered (certified) at the Village office of the National Land Agency. 4) The confiscated goods must clearly belong to the plaintiff, and the process needs to be carried out in a revindicatoir manner, and remain in possession

13 Sri Hartini, Setiati Widihastuti, and Iffah Nurhayati, 2017, Execution of Judge's Decision in Civil Dispute at the Sleman District Court, Journal of Civics Volume 14 Number 2, October 2017, p. 133 
of the Village Head or stored at the District Court Office. For further implementation, a report is made, while the Head of the District Court issues an order for an execution auction, which is addressed to the Registrar or Bailiff and in its implementation is assisted by DJKN cq KPKNL (State Property and Auction Service Office) by following the procedures as stipulated in the auction regulations. In situations whereby the confiscation of the guarantee is not carried out, and peace is reached between the two litigants, the implementation must be lifted (Risdianto 2020). ${ }^{14}$ This is in line with the Regulation of the Director-General of State Assets Number 2/KN/2017 concerning Technical Instructions for auctioning applications originating from district court decisions and small claim court through the using Article 6 number 2, namely through Court Execution Auctions.

The existence of guarantees in credit transactions at banks is regulated in material guarantee institutions in Law Number 10 of 1998 concerning Banking in article 8 paragraph (1). The law stated that banks are required to have confidence based on in-depth analysis of the intention with the ability of the debtor customer to pay off the debt or return the financing according to the agreement. This law is in accordance with the sharia principles in providing credit or finance. The principle regulated in the article shows a theory called "The Five C's of Credit," where one of the elements is "collateral," which is a guarantee given by the debtor for the risk received by the creditor on issued funds (Setiono 2018).

\section{d. Appeal Stage}

According to Article 21 of the 2019 Supreme Court Regulation, the legal effort for a simple decision is to file an objection. Application Stage of Objection consists of a list submitted to the Head of the District Court no later than 7 (seven) days after the decision is read or received. This is also done by signing the Deed of Statement of Objections before the Registrar along with the reasons and filling in the form of the Application for Objection. The Registrar's Office receives and checks the completeness of the Objection Application

14 Risdianto , (2020), Study on the Implementation of Perma No. 4 of 2019 concerning Amendments to Perma No. 2 of 2015 concerning Procedures for Settlement of Simple Lawsuits, Thesis Submitted to Fulfill Duties and Complete Requirements for Obtaining a Bachelor's Degree in Legal Studies,. p. 45 
file and is accompanied by a Memorandum of Objection made by the Applicant. Notice and Memorandum of Objections are submitted to the Respondent of Objection within 3 (three) days after receiving the application. The Respondent submits the Counter Memory of Objection to the Head of the District Court no later than 3 (three) days after notification of the Objection. After the Application file is declared complete, the Head of the District Court appoints a panel of judges led by a Senior Judge to examine and decide upon the application for Objection. The Panel of Judges examines objections which are carried out based on the Decision and the lawsuit filed as well as the Application and Memorandum of Objection, and the Counter Memory of Objection. In the examination of this Objection Request, the Judges Panel did not carry out additional examinations. This is different from the appeal at the High Court, where the Judges Panel at the High Court as a judex factie carry out additional examinations despite the lack of examination at the First Level Court. The decision on the Petition for Objection is pronounced no later than 7 (seven) days after the determination date of the Panel of Judges by the Head of the District Court. The decision on the objection request is the same as the previous decision, and the parties need to be notified no later than 3 (three) days after the decision on the Objection is made. This decision on the Application for Objection, other legal remedies such as Appeal, Cassation, and Review cannot be made because it has permanent legal force, therefore, it is carried out voluntarily. $\frac{15}{\text { The decision on }}$ a small claim court with a legal force is still carried out voluntarily by the parties. However, in situation whereby the parties do not comply, the decision is carried out based on the Civil Procedure Code, namely through the assistance of the District Court to execute. $\underline{16}$

Small Claims Court is a court that conducts a trial and renders a binding judgment which can be enforced like any other judgment. Although Small Claims Court can be less formal and less strict

15 Subekti, R. (2016). Kebijakan Pemberian Ganti Kerugian Dalam Pengadaan Tanah Bagi Pembangunan Untuk Kepentingan Umum. Yustisia Jurnal Hukum, 5(2), 376-394.

16 Arman Tjoneng, Small Claim Court ss Supreme Court Breakthrough In Resolving Cases In Court And Its Problems Faculty Of Law, Maranatha Christian University, Indonesia, p. 101, (Available From: Https://Www.Researchgate. Net/Publication/323340197_Gugatan_Sederhana_As_Terobosan_Mahkamah_Agung_dalam_Menyelesaikan_ Penumpukan_Perkara_Di_Pengadilan_Dan_Perjualan [Accessed May 17 2021]. 
when it comes to admitting evidence, the judgment of the court is as strong as anything else provided by the judicial system. A victim might resolve his case in other ways, however. One method of doing so is the promissory note, with or without an installment payment plan. The defendant would sign the note and then make the payment when required, or make the periodic (i.e., monthly) payments on or prior to the due dates. The note might or might not require the defendant to also pay interest. A Google search for promissory notes will reveal a wide range of choices. Care must be taken to select the right one; an attorney should be consulted if you are not sure. There are advantages and disadvantages to resolving a case through the use of a promissory note. The main advantage is that the parties do not have to go to court, and the proceedings do not have to be public. A key advantage to the victim is that, if the defendant fails to pay as required, the defendant will have virtually no chance of getting out of the obligation if and when the victim file suit on the promissory note. From the defendant's point of view, the key advantage would be that he can make installment payments; a secondary advantage would be that there will be no court judgment against him unless of course he defaults.

A second method is to require the defendant to confess judgment, meaning that he is stipulating to the entry of a judgment against him. Often the confession of judgment will be used to back up an installment payment arrangement. In other words, the confession of judgment will serve the function of the victim's security in the event that the defendant fails to make an installment payment as promised; if the defendant fails to make a payment as required, the confession of judgment would then be filed with the court, but not until then. The advantage to the victim is that he does not have to go to court at all to get his judgment, which would be the case if only a promissory note were used. The advantage to the defendant is that he can make installment payments, and there would be no court judgment against him unless he defaults.

\section{Conclusion}

Small Claims Court is a court that conducts a trial and renders a binding judgment which can be enforced like any other judgment. Although Small 


\section{P. Pujiyono, U. M. Pati, P. Pranoto, \& K. Tejomurti}

Claims Court can be less formal and less strict when it comes to admitting evidence, the judgment of the court is as strong as anything else provided by the judicial system. The bank and the customer both gain from a small claim court, as evidenced by some district courts where the bank dominates the submission. This lawsuit expedites the plaintiff's credit settlement in bad credit situations with a case value of less than $\$ 500$ million. The Court Execution Auction procedure uses microloans and auctions to carry out forced executions. Furthermore, the customer benefits since it avoids interest arrears, which are accumulating as a result of the prolonged settlement of cases while using traditional legal methods. A minor claim court in Indonesia, on the other hand, remains an option or alternative for the community. In simple circumstances, it has not become a duty or a requirement.

\section{References}

Anon. 2018. "Kebebasan Bank Dalam Memilih Lembaga Penyelesaian Kredit Macet Di Indonesia.” Lex Privatum 6(1).

Ariani, Nevey Varida. 2018. "Gugatan Sederhana Dalam Sistem Peradilan Di Indonesia." Jurnal Penelitian Hukum De Jure 18(3).

Arifin, R. (2020). Crimes and Society, How Do the Law Respond to Disruptive Conditions?. Law Research Review Quarterly, 6(1), i-iv.

Arifin, R. (2020). Legal Reform Discourse in Indonesia and Global Context: How Does The Law Respond to Crime. Journal of Law and Legal Reform, 1(2), 193-196

Asrun, A. Muhammad. 2004. Krisis Peradilan: Mahkamah Agung di Bawah Suharto. Jakarta: ELSAM.

Court, County. 2021. Case Tracking Information System. central Jakarta.

Court, Supreme. 2019. "Supreme Court Case Data Statistics." Retrieved January 10, 2020 (https://leip.or.id/Statistik-Data-Perkara-MahkamahAgung/,).

Darmawati, D., and A. Zainuddin. 2015. "Penerapan Keputusan Verstek di Pengadilan Agama." Al-Mizan 11(1).

Harahap, M. Yahya. 2009. Ruang Lingkup Permasalahan Eksekusi Hukum Perdata. Jakarta: Sinar Grafika. 
Hartini, Sri, Setiati Widihastuti, and Iffah Nurhayati. 2017. "Eksekusi Putusan Hakim Dalam Sengketa Perdata di Pengadilan Negeri Sleman." Jurnal Civics: Media Kajian Kewarganegaraan 14(2).

Ismiyanto. 2018. "Penyelesaian Kredit Bermasalah Melalui Gugatan Sederhana Berdasarkan Peraturan Mahkamah Agung (Perma) No. 2 Tahun 2015 tentang Tata Cara Penyelesaian Gugatan Sederhana." Spektrum Hukum 15(2).

Laras Asri Dwi Permatasari. 2019. "Prosedur dan Pelaksanaan Kartu Kredit

Nasabah Bank Bri Cabang Waru Sidoarjo,.” Perbanas School of Economics Surabaya.

Mertokusumo, Sudikno. 2006. Hukum Acara Perdata Indonesia, Edisi Keenam, 2006, Pg.175. 6th ed. Yogyakarta: Liberty.

Noor, Tajuddin. 2019. "Analisis Hukum Terhadap Penyelesaian Sengketa Hutang Piutang Melalui Akta Perdamaian (Studi Putusan Nomor: 1/ Pdt.G.S/2017/PN. Blg)." Jurnal Hukum Kaidah: Media Komunikasi Dan Informasi Hukum dan Masyarakat 18(3).

Pratiwi, Dyah Ayu. 2016. "Penyelesaian Hukum oleh Bank Terhadap Nasabah Kartu Kredit Yang Wanprestasi.” Brawijaya.

Risdianto. 2020. "Kajian Pelaksanaan Perma Nomor 4 Tahun 2019 tentang Perubahan Atas Perma Nomor 2 Tahun 2015 tentang Tata Cara Penyelesaian Gugatan Sederhana."

Saputri, Lisma Resky. 2019. "Legal Analysis of Bad Credit Cases at Bank Rakyat Indonesia Majene Branch No. : 35/Pdt.G.S/2018/Pn.Mjn.” University of West Sulawesi.

Setiono, Gentur Cahyo. 2018. "Jaminan Kebendaan Dalam Proses Perjanjian Kredit Perbankan (Tinjauan Yuridis Terhadap Jaminan Benda Bergerak Tidak Berwujud)." Transparansi Hukum 1(1).

Steven Weller, John C Ruhnka, And John A. Martin. 1990. American Small Claim Courts. edited by C. Whelan. oxford: Ckndompres.

Supreme Court. 2016. Statictics.

Supreme Court. 2020. Statistics.

Susatyo, Rakhmad. 2011. "Aspek Hukum Kredit Bermasalah di PT. Bank International Indonesia Cabang Surabaya." DiH: Jurnal Ilmu Hukum $7(13)$. 
Tejomurti, Kukuh. 2017. "Pertanggungjawaban Hukum yang Berkeadilan Terhadap Aparatur Pemerintah pada Kasus Pengadaang Barang dan Jasa.” Dialogia Iuridica: Jurnal Hukum Bisnis Dan Investasi 8(2).

Tjoneng, Arman. 2017. “Gugatan Sederhana Sebagai Terobosan Mahkamah Agung Dalam Menyelesaikan Penumpukan Perkara di Pengadilan dan Permasalahannya." Dialogia Iuridica: Jurnal Hukum Bisnis Dan Investasi 8(2).

Tracy, Karen, and Mary Caron. 2017. "How the Language Style of SmallClaims Court Judges Does Ideological Work." Journal of Language and Social Psychology 36(3).

Yunanto, Yunanto. 2019. "Menerjemahkan Keadilan Dalam Putusan Hakim.” Jurnal Hukum Progresif 7(2).

Vidmar, N. (1984). The small claims court: A reconceptualization of disputes and an empirical investigation. Law and Society Review, 515-550.

\section{ABOUT AUTHOR(S)}

Prof. Dr. Pujiyono, S.H., M.H is a Professor of Private Law at Universitas Sebelas Maret Indonesia. His area of expertise concerning Business Law, Contract Law, and Banking Law. Some of his research have been published on several journals, such as The Implementation of the Deferred Prosecution Agreement Concept to Corruption by Corporations with the Anti-Bribery Management System (SNI ISO 37001: 2016) (Padjajaran Journal of Law, 2021), Urgensi Pengaturan Mengenai Pertanggungjawaban Pidana Korporasi dalam Hukum Pidana di Indonesia (Gorontalo Law Review, 2021), and Consumer Protection in Resale Price Maintenance Practices (International Journal of Multicultural and Multireligious Understanding, 2021).

Umi Khaerah Pati, S.H., M.H., is a Lecturer at Department of Private Law, Faculty of Law Universitas Sebelas Maret, Surakarta Indonesia.

Pranoto, S.H., M.H., is a Lecturer at Department of Private Law, Faculty of Law Universitas Sebelas Maret, Surakarta Indonesia.

Kukuh Tejomurti, S.H. LL.M., is a Lecturer at Department of Private Law, Faculty of Law Universitas Sebelas Maret, Surakarta Indonesia. 